\title{
BISNIS ORANG SUNDA: STUDI TEOLOGI DALAM ETIKA BISNIS ORANG SUNDA
}

\author{
Didin Komarudin \\ Fakultas Ushuluddin UIN Sunan Gunung Djati Bandung \\ e-mail:pakdidin76@gmail.com \\ DOI: http:/ / dx.doi.org/10.30983/islam_realitas.v3i2.342
}

\author{
Diterima: 11 Oktober $2017 \quad$ Direvisi: 29 Desember $2017 \quad$ Diterbitkan :31 Desember 2017
}

\begin{abstract}
Bandung is known as a religious ethics proven by the appearance of its vitality in the reflection of its formal activity. It can be seen from the dynamics and rapid of the religious activity, such as formalistic of praying, the festive of Ramadan, numerous of majelis ta'lim or the number of Muslims who perform the pilgrimage in every year, both in quality and quantity. It certainly affects the busininess activities as modern managementoriented to professional interpreneneurship act. This research gives evidence that Sundanise business ethics influences the guiding frame of every business policy. Morever, the theological factor plays an important role in encouraging a man to be successful in business. CV. Batu Gunung Padakasib (BGP) which is located in Cikancung-Bandung, Tapin District, has represented many significant findings concerning relation between ethics and social business theology in the policy that may be regarded as causal relation in business success.
\end{abstract}

Keywords: Entrepreneurship, Business Ethics, Theology Social-Business.

\section{Abstrak}

Bandung dikenal sebagai suku atau etnik religius terbukti dari penampakan wujud vitalitasnya dalam refleksi aktivitas formalnya. Hal itu dapat dilihat dari perjalanan dinamika keagamaan yang intensitasnya cukup kental seperti aktivitas ibadah yang semarak seperti formalistik shalat, meriahnya Ramadhan, banyak majelis ta'lim atau banyaknya kaum Muslimin yang melaksanakan ibadah haji dalam setiap tahun, baik secara kualitas maupun kuantitasnya. Hal ini tentu mempengaruhi kegiatan bisnisnya yang dimana merupakan manajemen modern berorientasi profesional kewirausahaan tindakan. Penelitian ini memberikan bukti bahwa etika bisnis yang diterapkan oleh Suku Sunda mempengaruhi pada pedoman kerangka setiap kebijakan bisnis. Terlebih lagi, faktor teologis memainkan peran penting dalam mendorong manusia untuk menjadi sukses dalam bisnis. Ada CV. Batu Gunung Padakasih (BGP) yang terletak di Cikancung-Bandung, Kabupaten Tapin, telah mewakili banyak temuan yang signifikan mengenai hubungan antara etika dan teologi bisnis sosial dalam kebijakan yang dapat dianggap sebagai hubungan kausal dalam keberhasilan bisnis.

Kata Kunci: Kewirausaan, Etika Bisnis, Teologi Sosial-Bisnis

\section{Latar Belakang}

Orang Bandung sebagai orang religius telah menampakan wujud vitalitasnya dalam refleksi aktivitas formalnya. Hal itu dapat dilihat dari perjalanan dinamika keagamaan yang intensitasnya cukup kental di tengah orang. Kalau tolak ukurnya adalah aktivitas ibadah yang semarak seperti formalistik shalat, meriahnya Ramadhan, banyak majelis ta'lim atau banyaknya kaum Muslimin yang melaksanakan ibadah haji dalam setiap tahun, baik secara kualitas maupun kuantitas sudah tentu tidak diragukan lagi. ${ }^{1}$ Namun dalam dimensi subtansial teologis yang bisa merasuk ke dalam jiwa aktivitas koherensif apakah turut menyertai secara inheren pada perspektif sosial, sebagai bagian dari ibadah dalam bentuk lain, tentu masih diperlukan pelacakan.

1 Hafiz Anshary AZ. "Keberagamaan Orang Banjar", dalam Laporan Penelitian Abdul Sani, Islam dan Etika Bisnis Pengusaha Banjar di Kalimantan Selatan (Banjarmasin: Pusat Penelitian IAIN Banjarmasin, 2001), h. 6. 
Dalam konteks penelitian ini, yang merupakan ringkasan hasil penelitian penulis, khusus dalam aktivitas etika bisnis pengusaha Bandung yang dilaksanakan di sejumlah perusahaan besar milik orang Bandung, ternyata masih perlu ditindaklanjuti lebih mendalam lagi. Wawasan teologis yang dimiliki sebagai khazanah akidah keberagamaan menurut dugaan sementara, belum mampu menjadi paradigma dan etos dalam memunculkan etika yang komprehensif pada tataran aktivitas bisnis. Persoalan lain, ada anggapan bahwa aktivitas bisnis secara profesional tidak mempunyai keterkaitan kontekstual dengan penjiwaan nilai-nilai keislaman seseorang. Artinya, kesuksesan bisnis seseorang tidak bisa distigmatisasi oleh adanya sesuatu di luar koridor khas yang terkait dengan manajemen bisnis. Bertitik tolak dari pandangan itu, maka penelitian dilakukan dan ulasan ringkasan ini mengambil beberapa elemen penting temuan yang berkenaan dengan etika bisnis dalam perspektif teologis.

Adapun masalah yang dibahas dalam tulisan ini adalah nilai-nilai teologis dalam perilaku dan etika bisnis pengusaha Bandung di perusahaan-perusahaan daerah yang dimiliki orang Bandung. Fokus arahannya pada refleksi nilai-nilai etika dalam perilaku manajemen bisnis, namun perlu juga dikembangkan aspek lainnya yaitu tentang teologis. Namun keterbatasan waktu, sementara ini hanya mampu ditampilkan satu perusahaan saja, yaitu perusahaan Batu Gunung Padakasih (BGP) yang terletak di Cikancung, Kabupaten Bandung.

Manfaat penelitian diharapkan dapat memberikan konstribusi keilmuan tentang praktek bisnis orang Bandung yang ada di Jawa Barat yang terkait dengan nilai-nilai etika dan teologis. Selain itu, secara praksis kontemporer diharapkan dapat memberikan landasan teoritik dalam upaya mendeskripsikan secara utuh dan komprehensif mengenai aktivitas budaya ekonomi umat Islam orang Bandung. Bagi kalangan bisnis adalah dalam upaya meningkatan vitalitas sekaligus menjadi referensi di kalangan mereka baik secara lokal maupun nasional. Sehingga dengan demikian, pada gilirannya menjadi pilar yang bisa dijadikan pondasi kehidupan umat Islam dalam merekonstruksi praktik-praktik bisnis berjangka panjang dan mapan.

\section{Metodologi Penelitian}

Metode penelitian yang dilakukan ini berbentuk penelitian lapangan (field research) dengan pola naturalistik, untuk memudahkannya ditetapkan beberapa acuan yaitu: Subyek penelitian adalah orang bandung yang mempunyai aktivitas bisnis yang bermanajemen baik secara formal, legal maupun dalam kategori modern, yang difokuskan secara kasus pada CV/PT. Batu Gunung Padakasih yang berlokasi di Cikancung Kabupaten Bandung yang diperhitungkan mempunyai vitalitas dan aktivitas bisnis yang cukup dinamis.

Obyek penelitian adalah tentang aspekaspek teologis dan aspek-aspek etika dalam bisnis. Data penelitian meliputi tentang gambaran sejarah, visi-misi perusahaan, SDM, fasilitas, modal dan perkembangan bisnis orang Bandung secara manajemen. Data tentang etika-etika bisnis di antaranya kejujuran, keadilan, kepercayaan, dan permodalan.

Adapun data tentang aspek-aspek teologis di antaranya adalah; a) Paham tentang dinamitas hidup, nasib dan keberuntungan manusia; b) Kepercayaan terhadap Tuhan terkait dengan keberuntungan dan nasib; c) Keadilan atas persamaan hidup manusia di hadapan Tuhan; d) Potensi diri, modal dan kemampuan manusiawi; e) Hubungan manusia dengan Tuhan dan alam semesta; dan, f) Campur tangan Tuhan terhadap keberhasilan manusia. 
Sumber data didapatkan dari pimpinan perusahaan (direksi), pimpinan perusahaan menengah (branch, kadivisi, kabag, kepala mandor), karyawan, dan orang yang langsung terlibat dalam aktivitas bisnis.

Teknik pengumpulan data, melalui observasi langsung dan partisipan, wawancara mendalam non-struktur, dan dokumenter. Teknik kerja menganut pola snowballing (menggelindingkan bola salju), yaitu dengan cara melacak data secara menggelindingkan pertanyaan dari satu ke lain pertanyaan dari yang sedikit ke proses ganda, dan dari yang kecil menjadi lacakan besar dan terus menerus secara bertahap dan tentu berkelanjutan. Pencatatan, pemilihan (kategorisasi), analisis check and recheck, kecermatan mendeskripsi data agar jadi bahan berharga ditentukan oleh peneliti. Walaupun demikian, obyektivitas tetap menjadi keutamaan yang berharga.

Penelitian ini dianalisis melalui dua tahap penelitian, pertama penelitian dilakukan dalam pra-riset dan saat riset, yang di dalam langkahlangkah penelitian mengacu pada subyek formal tentang aktivitas perusahaan secara gradual, umum dan deduktif. Aktivitas perusahaan secara umum dijadikan sebagai obyek penelitian. Pola-pola temuan data di lapangan lebih dipresentasikan pada data deduktif, tersaji dalam tarikan simpulansimpulan. Data benar-benar sudah diklarifikasikan untuk hasil temuan. Proses pemaparan tidak apa adanya, melainkan sudah mengalami sterilisasi pemahaman, simbiosis gabungan antara momot dengan asumsi, antara priori dan apriori, dan tersaji dalam proses analisis terus menerus.

Selanjutnya, ada riset lapangan penulis terjun lagi ke lapangan, meneruskan pelacakan data secara simultan, akurat dan cermat dengan pola-pola penelitian induktif probabalistik Popper dengan teknis yang dilakukan Moleong dan Spradley. Cara kerja yang ke dua itu, pemilahan data-data benarbenar mengacu secara induktif, apa adanya, tampilan hasil penelitian digubah dalam penalaran, kemudian pemaparannya benarbenar reflektif apa adanya. Pada kajian analisis menggunakan teknis tabolasi domain besar, analisis taksonomi, analisis kontras, dan analisis komponensial budaya. Cara kerja metode demikian untuk memilahkan induktifikasi data formal material dengan data subtansial penalaran peneliti. Reduksionalisasi data dilakukan melalui instrumen observasi mendalam, partisipatif kolektif dan wawancara nonstruktural namun terbuka dan menyentuh secara dalam persoalan pokok data yang mau diteliti. Data induktif tersaji berdasarkan ungkapan nyata, sesungguhnya dan apa adanaya disodorkan oleh subyek. Dari data yang terkumpul diklasifikasi utuh sesuai keinginan penulis. Data-data simpulan itulah yang disajikan dalam sari penelitian ini, khususnya yang terkait dengan tiga perumusan masalah di atas. Setelah itu baru penyajian data deskriptif secara utuh.

\section{Deskripsi dan Profil Pebisnis Sunda}

H. Agus, termasuk orang yang percaya penuh atas nasib manusia, dengan usaha dan kerja keras. Selain itu do'a dan kedekatan dengan ulama (habib-habib) menjadi bagian usahanya untuk mendapatkan "berkah" kesuksesan dalam berusaha. Berkah itu didapatkan dengan selain menjalin komunikasi kuat dan intens dengan ulama, termasuk guru Fathul Ulum H. Muhammad Ubuh Cikancung Hilir Cikancung.

Istilah yang sering diungkapkannya adalah bahwa rizki tidak turun dari langit, melainkan didapatkan dengan bekerja keras dan membanting tulang. Pengalaman beliau diungkapkan dengan pernyataan bahwa "aku waktu merintis batu pondasi ini, sering keluyuran ke atas-atas gunung. Bukan hanya di siang hari tetapi di malam hari bahkan sampai jam dua malam masih berada di tengah hutan dan di atas gunung, untuk membuktikan untuk menjadi kaya seperti ini, tidak merupakan 
faktor warisan atau keberuntungan sematamata".

Selain bekerja keras dan berdo'a kepada Tuhan, kita memerlukan bantuan orang lain baik saudara sendiri maupun kerabat dan siapa saja yang bisa diajak bekerja sama untuk membangun usaha sesuatu. Hubungan dengan Tuhan benar-benar dibina dengan baik, melalui sholat dan zakat (sedekah yang diperbanyak). Hal-hal yang seperti sudah dicanangkan justru sebelum kesuksesan seperti sekarang ini. Pada intinya nasib juga ditentukan oleh banyak berhubungan dengan manusia dan berbuat baik dengan alam atau istilahnya janganlah banyak mengeluh terhadap situasi kondisi hidup, seperti saat kepanasan atau kehujanan. Terima saja keadaan alam seperti itu apa adanya, sehingga berkat demikian jiwa rasa berserah diri kepada yang mempunyai alam cukup menimbulkan rasa optimis diri terhadap apa saja yang diraih. Memperbanyak minta do'a kepada siapa saja, termasuk pada ulama-ulama terkenal.

Walaupun demikian, kunci utama do'a ada pada diri sendiri ditunjang dengan usaha dan kerja keras. Tidak ada kegagalan yang mutlak, hanya kegagalan sementara. Begitu juga kesuksesan tidak ada yang tidak bisa dijadikan harapan. Semua orang bisa saja sukses dan kaya tergantung bagaimana usaha berusaha mencapai kekayaan dan kesuksesan itu. Bekal untuk kaya ditentukan oleh jenis usaha dari seseorang. Kalau usaha kecil mengharapkan untung besar, berarti tidak sebanding. Usaha besar bisa mendatangkan keuntungan berlipat ganda. Tergantung modalnya, memang resikonya juga besar.

Tuhan adil saja memberikan keuntungan kepada orang yang memiliki modal besar dan resiko besar. Sebaliknya memberikan keuntungan kecil kepada pemilik modal kecil.
Di sinilah yang perlu dipahami oleh pelaku bisnis. $^{2}$

Menarik dikemukakan pendapat informan; Encep dan Hasanudin bahwa perusahaan BGP merupakan perusahaan besar yang sepertinya menjadi milik masyarakat karena keuntungan yang didapatkan sementara ini banyak dibagi-bagikan kepada masyarakat untuk kepentingan pembangunan masjid, langgar, musholla, sekolah-sekolah Islam, pesantren, dan lembaga sosial lainnya. Terutama pada bulan Ramadhan, puluhan juta rupiah lebih diperuntukkan sebagai zakat perusahaan yang dibagi, termasuk ke Yayasan sosial dan pendidikan Asy-Syifa. Bahkan setiap bulan masing-masing kaum dhuafa dan anak yatim piatu maupun yatim yang berjumlah lebih 30 orang mendapatkan santunan uang Rp. 10.000 perjiwa. Hal seperti ini sudah menjadi kebiasaan lama, dilakukan oleh perusahaan BGP. Orientasi ibadah sosial dimunculkan sebagai bagian dari kebijakan perusahaan secara formal dan intensif.

Rezki menurut responden memang didapatkan dari Tuhan, namun kerja keras untuk mendapatkan itu tidak mudah. Karenanya wajar, kalau perusahaan merasa berterima kasih kepada Tuhan, melalui cara mengeluarkan sebanyak $2,5 \%$ total fee hasil penjualan batu pondasi diperuntukan untuk membantu lembaga-lembaga keagamaan.

\section{Prinsip Etika dan Teologis dalam Bisnis Orang Sunda}

Kajian untuk mendalami persoalan hasil penelitian ini, diarahkan kepada dimensi etik dan teologis dalam perilaku bisnis. Namun sebelum sampai kepada itu, tentu diperlukan seperangkat pemahaman reflektif seseorang

${ }^{2}$ Hasil penelitian dari tanggal 5 Januari sampai 5 Februari tahun 2016 terhadap perusahaan BGP dan wawancara mendalam dengan $\mathrm{H}$. Agus di kantor dan beberapa wawancara di kesempatan lainnya, dengan pertemuan ke berbagai sumber intern perusahaan seperti H. Entoh. 
dalam paradigma psikologis. Orang Bandung, atau dalam kaitan penelitian ini, pengusaha Bandung untuk sementara dapat dikategori sebagai pemeluk agama Islam dengan berbagai nilai di dalam kepribadiannya. Nilai (value) menurut Edward dan Renes diterminologikan sebagai sesuatu berharga yang mempunyai konotasi kebaikan. ${ }^{3}$ Apa yang diungkapkan sebagai nilai dalam konteks luas tentu memerlukan sebuah penghargaan "an assessment of worth. ${ }^{\prime \prime}$ Merujuk pada pemahaman itu, maka nilai itu ada di dalam jiwa seseorang yang secara pragmatik memiliki potensi berharga dan bisa direfleksikan ke permukaan sebagai perwujudan dari pemahamanpemahaman yang bersentuhan kepada keyakinan, kekuatan jiwa dan nilai-nilai kemuliaan, baik berasal dari agama, budaya atau adat-istiadat yang terhujam di jiwa kemudian terwariskan dalam bentuk perilaku empiris. Di sinilah perilaku ekonomi itu dipengaruhi oleh budaya lokal yang menurut Deni bahwa perilaku masyarakat lokal juga dipengaruhi nilai budaya di samping nilai agama yang mereka anut ${ }^{5}$.

Nilai bisa bersinergi dengan berbagai bobot lain, dalam kontek ini, nilai berasimilasi dengan bentuk-bentuk lain. Di dalam Islam, ajarannya diwariskan sebagai nilai. Nilai itu tertransformasikan kepada formula seperti teologi, fikih maupun akhlak. Nilai-nilai teologis hanya bisa dikonstruksikan dan diimplementasikan dalam aspek religius berbentuk normatif. Ketika pengejawantahan refleksi teologis ke permukaan, ia membentuk

3 Paul Edward, The Encylopedia of Philosophy (London \& New York: Macmillan Publishing \& Co, 1972), h. 324. Degobart D Renes, Dictionary of Philosophy (Now Jersey, Leftlefield, Adam and Co, New Jersey, 1976), h. 4-5.

4 Vincent Barry, Applying Ethics (California: Worth Publishing Company and Wads Worth, 1989), h. 4.

${ }^{5}$ Miharja, Deni, "Keberagaman Masyarakat Adat Cikondang dalam Menghadapi Modernisasi", Islam Realitas: Journal of Islamic \& Social Studies, 1.1, 2015, h. 95101. aksioma wacana yang muncul menyiratkan simbol-simbol eksis perilaku. Eksistensi perilaku ini berwujud dalam konteks etika. Nilai-nilai itu sementara bisa terlihat dalam figur khusus, yaitu figur $H$. Agus sendiri. Sedangkan yang lain, yang sementara dalam penelitian ini sebagai kepanjangan tangan kebijakan pimpinan di dalam perusahaan. Nilai-nilai Islam ke permukaan dalam praktek bisnis, hanya saja tergantung sangat individual senter, yaitu figur direktur utama secara khusus. Yang lain-lain, tidak banyak memberikan andil terhadap sinergi kerja kolektif unsur pemegang kendali perusahaan. Sementara ini, hanya direktur utama yang dapat terlacak dalam tampilan mengenai peran penguasaan nilai Islam dalam praktik bisnis. Etika yang terjabarkan dalam penyertaan perilaku itulah, sementara ini dipakai sebagai bingkai kajian-kajian kontemporer wacana aktivitas umat Islam yang lebih relevan, yaitu pada persoalan etika bisnis. Dalam kajian pustaka, bahasan etika bisnis khususnya di Jawa Barat yang mengelimansi orang Bandung, dirasa masih kurang. Ada beberapa kajian terdahulu seperti yang dilakukan Jahja ${ }^{6}$, Thaib ${ }^{7}$, dan Irham $^{8}$, yang mengkaji etos kerja dalam konteks Islam, baik dari sumber al-Qur'an maupun dalam penafsiran mazhab teologi Asy'ariyah.

Alfani Daud, pernah melakukan penelitian tentang Islam dan dan orang Banjar, namun tidak berbicara tentang aspek-aspek bisnis dalam perilaku. Penelitian yang berwujud disertasi tersebut hanya mengungkap kultur Banjar dalam dimensi antropologik, terutama elemen-elemen kebudayaan dalam

${ }^{6}$ H.M. Zurkani Jahja, "Etos kerja dan Teologi Asy'ariyah”, Jurnal Antasari, Vol. X, 1988, h. 23-31.

${ }^{7}$ Erwin Jusuf Thaib, "Al-Qura'an dan As-Sunnah Sebagai Sumber Inspirasi Etos Kerja Islami”, Jurnal Dakwah Tabligh, Vol. 15, No. 1, 2014, h. 1-9.

8 Mohammad Irham, "Etos Kerja dalam Perspektif Islam”, Jurnal Substantia, Vol. 14, No. 1, 2012, h. 11-23. 
konstruk sosial temporer. ${ }^{9}$ Dalam temuan hasil penelitian ini, Asy'arisme dalam perilaku tidak identik dengan paham akidah dominan yang komunal dianut oleh banyak orang. Ada semacam tafsiran terhadap upaya-upaya nasib lebih antroposentris daripada teosentris. Etika bisnis sebenrnya merupakan bagian transformatif paradigma dari etos dinamis seseorang yang memperjuangkan nasib hidup, yang di dalam istilah teologi Protestan Calvinis memperjuangkan nasib menjadi terpilih (beruf, yang diperhitungkan terpilih), dan memenuhi jalur-jalur supaya menjadi uang terpilih melalui seleksi keberhasilan ekonomi. ${ }^{10}$ Istilah yang dikutip dari Weber sebagai etos kerja dari aktivitas ekonomi kaum Calvinis.

Etos kerja itu mendesain normatif secara eksistensi ke permukaan menjadi nilai-nilai etik atau etika yang bersinerji dengan bisnis. Penulis mencoba merekonstruksi teori berdasarkan kajian pustaka tentang etika bisnis ini, dengan mengambil formulasi teologis sebagai determenisasi pemilahan data temuan untuk menyelaraskan dengan faham-faham keagamaan orang Bandung yang notabene Asy'arisme di wilayah akidah. Artinya temuan di lapangan di dalam penelitian ini ditransformasikan kepada kajian teologis. Dari kenyataan di permukaan H. Agus sebagai pemilik perusahaan dan sebagai pionirnya, sama sekali tidak bisa disamakan secara komunal dengan orang Bandung yang sepaham secara Asy'arisme. Etika bisnis menjadi wacana mutakhir dalam perbincangan kontemporer, karena terkait dalam berbagai dimensi normatif. Sementara ini, krisis

9 Alfani Daud, Islam dan Masyarakat Banjar (Jakarta: PT. Raja Grafindo, 1997), h. 32. Bandingkan juga dengan penelitian Bagus Mohammad Ramadhan dan Muhammad Nafik Hadi Ryandono, "Etos Kerja Islami pada Kinerja Bisnis Pedagang Muslim Pasar Besar Kota Madiun", JESTT, Vol. 2, No. 4, 2015, h. 274-287.

${ }^{10}$ Lihat Lutz Kaelber, "Max Weber's Protestant Ethic in $21^{\text {st }}$ Century", International Journal of Politics, Culture and Society, Vol. 16, No. 1, 2002, h. 133-146. multidimensi di dalam kehidupan ekonomi bangsa ini juga ditengarai kuat akibat tersingkirnya etika di dalam kehidupan kaum entreprenur. Tidak berlebihan tuduhan itu. Munculnya konglomerasi, praktik bisnis yang sarat KKN, label bagi pengusaha kakap sebagai konglomerat hitam, mewarnai isu nasional di masa reformasi.

Etika bisnis menurut Musa dianalogikan dalam ungkapan "Business ethics is the behaviour that corporations must adhere to in carrying out its day to day operations within the environment where it operates and probably sometimes outside the community" ${ }^{\prime 1}$. Etika bisnis seyogyanya inklusif dalam praktik perilaku bisnis yang dianggap sebagai aturan main, sehingga menjadi cerminan kebijakan secara menyeluruh dalam pengambilan keputusan bisnis. Di dalam berbagai perusahaan multi-internasional, persoalan etika bisnis jadi wacana yang masih diperdebatkan. Memang, perusahaan besar seperti Mc. Donald yang merambah ke mancanegara, dalam berbagai session publisitasnya selalu menekankan makna penting etika bisnis. Sebagaimana dilansir oleh Soderberg, bahwa aspek membangun kepercayaan konsumen, mengembangkan makna transparansi bisnis, bahkan menekankan aspek pelayanan menjadi trend kunci kesuksesan mereka dalam membuka jaringan global. ${ }^{12}$

${ }^{11}$ A.O. Musa, "Perceived role of ethics and social responsibility in the insurance industry: Views from developing country", Journal of Knowledge Globalization, Vol. 1, No. 2, 2008, h. 41-59. Bandingkan dengan D. Collins, "Designing ethical organizations for spiritual growth and superior performance: An organization systems approach", Journal of Management, Spirituality and Religion, Vol. 7, No. 2, 2010, h. 95-117.

12 Norman R. Soderberg, Public Relation for The Entrepreneur and Growing Business (Chicago: Illionis Probus Publishing Company, 1986), h. 32. Buku yang banyak mengupas tuntas aspek pertumbuhan global perusahaan raksasa dunia, di antaranya MC. Donald dan grupnya, yang merajai makanan pangan cepat saji, sebagai fakta hajat manusia sejagad, dan itu disajikan secara fast-food di restoran-restoran besar di kota-kota metropolitan. Sesuatu yang menarik, ternyata menurut 
Aspek etika bisnis yang turut menyertai bisnis diperlukan adalah diantaranya yang terpenting yaitu makna kejujuran, kepribadian dan kehandalan moral sebagai tindak privasi kunci seseorang menjadi pialang penguasa pasar bisnis, sebagaimana dikemukakan oleh Jarden dan Call bahwa etika sebagai landasan moral privasi dalam tindakan dianggap menjadi prinsip menuju semangat keberuntungan nasib. ${ }^{13}$

Pebisnis tidak bisa berbisnis sendiri, ia mutlak mengelola sebuah keniscayaan kerjasama (networking team), karena itu, seorang pemimpin puncak perusahaan besar perlu meletakan pondasi rules game dalam aturan mesin bisnis supaya ia dicontoh oleh bawahannya. Mengedepankan profil kejujuran dan keterpercayaan bawahan terhadap atasan atau sebaliknya, membangun sinergi sosial pelanggan, memantapkan relasi pasar yang prokultur dan lingkungan plus beradaptasi dengan jiwa pembeli, menjadi taruhan meraih pangsa pasar bisnis. ${ }^{14}$ Munculnya etika kejujuran dan keterpercayaan bisa termanifestasi ke permukaan hanya bila seseorang telah mengedepankan nilai-nilai itu dalam kerangka konseptual hidup dan jadi bagian yang mewarnai perjalanan empiris perilaku. Titik temu nilai ini, bisa dilacak secara teologis bahwa keyakinan akan eksistensi Tuhan dalam alam sementara di dalam ajaran Islam sangat kongkret berupa nilai ihsan kehidupan, yang diformulasi oleh interpretasi bahasa hadits "Melihat Allah dalam wujudNya". Arti firman Allah, kemanapun engkau menghadapkan wajahmu", dan banyak

data survey. Soderberg, aspek keterpercayaan layanan memuaskanlah yang menjadi orang ketagihan menjadi pelanggan restoran cepat saji tersebut.

${ }_{13}$ Des Jarden and Mac Call, Contemporery Issues in Businees Ethics (California: Word Worth Publishing Company, 1989), h. 3-7.

${ }^{14}$ John Donaldson and Irene Fafaliou, "Business Ethics, Corporate Social Responsibility and Corporate Governance: a Review and Summary Critique", European Research Studies, Vol. VI, No. 1-2, 2003, h. 90110. lagi ungkapan senada. Bertindak jujur dan dapat dipercaya, bukan sebuah kebetulan atau sesuatu yang otomatis. Proses itu mengalami daya empiris panjang dalam penghayatan dan pengalaman, apa yang diistilahkan sebagai ekspresi beragama dalam pengalaman keberagamaan menyangkut pemahaman yang dalam terhadap kesadaran beragama seseorang, yang mencuat ke permukaan sebagai sebuah implementasi hidup bersumber dari keyakinan terhadap yang agung dan menjadi bagian terdalam di dalam jiwa. ${ }^{15}$ Dari sinilah proses teologisasi prilaku tanpa rentan panjang, simultan dan berkelanjutan yang tentu sangat riskan kalau mampu muncul seketika. Ia dapat muncul dalam konstruksi kemungkinan yang hanya terjadi tidak berdasarkan kontemplasi pengendepan secara merekat dan melintas batas-batas pencerahan iman.

Makna kejujuran dalam hasil temuan, memang masih kesulitan dibuktikan secara aplikatif dalam waktu yang relatif pendek, hanya selama satu bulan dalam penelitian ini. Namun ungkapan-ungkapan itu menyiratkan adanya kesungguhan pelaku mencerminkan diri bertindak seuai pemahaman yang diberikannya. Memang ada beberapa kali konfirmasi cek silang dengan bawahanbawahan, menurut informasi menurut bawahan, "Bos Bageur" (istilah yang diberikan kepada H. Agus), sangat keras mendisiplinkan diri terhadap kejujuran, termasuk ketika kepercayaan beliau berikan kepada seseorang, mutlak dijunjung tinggi, oleh yang memegang kepercayaan itu.

15 Lihat Paul E. Johnson, Psychology of Religion (New York: Abingdon Press, 1959), h. 162-163. Yang menggambarkan pengalaman keagamaan seseorang yang tertuju kepada keagungan sesuatu dan berharap mendapatkan hubungan lebih baik dengan sesuatu yang agung, sebagai refleksi teologis jiwa seseorang untuk merefleksikan tindakannya, juga lihat buku lain tentang pengalaman keberagamaan William James, Religius Expreance (New York: Hand books, American University, 1986), h. 213. 
Dalam Iiz, konvergensi pencerahan ini menjadi paradigma teologis, dalam dinamika kekuatan hidup, penggapaian nasib, proses keberuntungan untuk menjadi yang sukses secara utuh dan kuat bermuara pada keyakinan diri sebagai potensi, bukan sesuatu yang berada di luar, termasuk Tuhan ${ }^{16}$. Pebisnis $(H$. Agus Abdullah), tampaknya berusaha secara inheren menggandalkan hal-hal yang prinsip dalam wacana bisnis, entah itu aspek manajemen, aspek profesionalisme SDM, permodalan, strategi maupun taktik yang sudah ada ukuran baku, teoritik, dan mudah dilaksanakan. Sangat jarang mereka mengklaim dalam konteks keberuntungan nasib an sich terhadap kesuksesan bisnis. Etika dan teologis berkomulasi menjadi bingkai, etika sebagai pengjawantahan aspek teologi, sementara teologi sebagai subtansi esensial dari paradigma tindakan bisnis. Dengan kata lain, manakala etika diperbincangkan dalam aktivitas perilaku bisnis, maka yang mewarnai refleksi tindakan adalah seperangkat yang menjadi dasar keyakinan agamanya, seperti kepercayaan yang teguh terhadap prinsip kejujuran, prinsip keterbukaan dan saling menghargai, prinsip keterpercayaan dalam bermitra bisnis dan prinsip keadilan dalam pemerataan keuntungan. Dalam Asyari, keadilan terhadap pemerataan keuntungan inilah yang dijadikan indikator sementara ini, dalam mengungkapkan adanya keadilan di dalam keluar dari garis kemiskinan menuju kesejahteraan ${ }^{17}$.

Seperti diketahui bahwa konstruksi teologi orang Bandung mayoritas kalau tidak dikatakan hampir seratus persen berpaham

\footnotetext{
$16 \overline{\text { Izmuddin, Iiz, "Menata Regulasi Pegadaian }}$ Syariah (Upaya Menerapkan Al-Maqasid dan Meminimalkan Kesenjangan Sosial)", Islam Realitas: Journal of Islamic \& Social Studies, 2.2, 2016, h. 165-178.

17 Asyari, Asyari, "Model Strategi Bertahan Hidup Rumah Tangga Miskin (Sebuah Literature Review)", Islam Realitas: Journal of Islamic \& Social Studies, 2.2, 2016, h. 153-164.
}

Asy'ariyah (Sanusiah). Namun dalam konteks luas, implikasi paham teologi ini beraneka ragam tergantung yang populer muncul ke permukaan. Bisa jadi ada bias dan maknamakna transformatif ketika wilayah paham itu turut berkolaborasi dalam aktivitas ritual, aktivitas ibadah formal, dan aktivitas sosialpolitik. Ternyata benar dugaan sementara bahwa akumulasi praktik bisnis, tidak sepenuhnya dijiwai oleh paham Asy'ari, apalagi konotasi diarahkan kepada etos kerja. H. Agus dalam mendayung perusahaannya sangat menjunjung tinggi etos kerja dalam menjalankan perusahaannya.

Menurut Rahman, teori-teori ekonomi Islam sementara ini dibangung berdasarkan kajian normatif, masih belum mampu menyentuh dan menjawab dinamika pembangunan umat Islam di bidang ekonomi bisnis ${ }^{18}$. Walaupun tidak menafikan sumbangsih pemikiran seperti $H$. Anang Abdulkohar, dan tokoh lainnya, namun sementara ini, konstruksi teoritik tentang etika bisnis atau aktivitas bisnis dalam koridor Islam, masih terasa lemah di dalam datarandataran praksis. Di sinilah diperlukan pelacakan transformatif kontekstual diperlukan sebagai khazanah tambahan realitas.

Wujud aktivitas ekonomi umat dalam bentuk real sebagai perilaku bisnis sangat perlu direfleksikan secara deskriptif dengan menggunakan realitas-realitas kajian yang mendalam dan memakan waktu lama, agar subtansi teoritik tentang aktivitas bisnis itu dapat terpotret jelas ke permukaan dalam wilayah yang bisa dipertimbangkan sebagai nilai empiris, bukan normatif. Meletakan pondasi itu, sementara ini mengalami kesulitan dari para tokoh-tokoh analis dan pemikir ekonomi Islam, karena memang belum

\footnotetext{
18 Rahman, Addi, "Pos-Islamisme "Ilmu" Ekonomi Islam di Era Urban dan Multikulturalisme", Islam Realitas: Journal of Islamic \& Social Studies, 1.2, 2015, h. 165-172.
} 
sepenuhnya didapatkan dalam penelitianpenelitian lapang dan riset mendalam, terencana dan dengan metodologi-metodologi absurd yang memunculkan refleksi realitas subyek yang diteliti.

Wawasan teologis dalam etika bisnis diperlukan untuk mengkaji seberapa dalam dan kuat terkait implikasinya, karena bagaimanapun aktivitas kolektif kehidupan tidak bisa dipisahkan dari aspek kepercayaan dan keyakinan dalam hidup seseorang apakah sebagai Muslim yang taat atau tidak. Paham tentang takdir, nasib dan kebebasan meilih hidup sukses atau tidak sebenarnya tergantung dari keyakinan dan kepercayaan yang mendasari. Dalam paham kalam klasik, paham Mu'tazilah yang sangat antroposentris mewarnai perilaku kehidupan. Sebalik paham Jabariyah yang sangat teosentris juga demikian. Kalau ditilik dari perspektif totalitas aktivitas bisnis, ada kecenderungan menafikan paham yang teosentris dalam keyakinan dan perbuatan manusia. Manusia sendiri yang berbuat dan bertanggung jawab atas perbuatannya, jadi perilaku bisnis baik wujud maupun hakikatnya adalah diciptakan oleh manusia, bukan oleh Tuhan. ${ }^{19}$ Keyakinan demikian, diasumsikan sebagai keyakinan manusia Muslim yang dinamis, yang mau mengejar keuntungan dan keberuntungan hidup, bukan manusia yang pasrah terhadap nasib dan menunggu rizki dari Tuhan sematamata. Berdasarkan itu pula, manusia bisnis, adalah manusia yang memperhitungkan nasib itu selalu diperjuangkan olehnya, bukan semata-mata ditentukan oleh Tuhan. Hal demikian, ditambahkan secara sosiologis bahwa sebagian keuntungan perusahaan dibagi-bagikan kepada pembangunan tempat ibadah dan pembangunan lembaga pendidikan agama. Membagibagikan keuntungan itulah

${ }^{19}$ Lihat pendapatnya Muhammad An-Najjar dan Ad-Dirar, ibn Amr, tentang faham kebebasan manusia dalam al-Syahrastani, Al-Milal Wa an-Nibal, I (Kairo: Dar al-Fikr, 1951), h. 87-89. indikator sementara bahwa secara praktek sosial bisnis dianggap sebagai bagian memenuhi tuntutan orang yang memang membutuhkan perhatian dan kepedulian sosial oleh seorang pelaku bisnis, dalam hal ini sebagai kebijakan perusahaan BGP.

Figur individu H. Entoh memang belum memahami makna-makna sesungguhnya dari paham Asy'ariah, hanya berdasarkan ungkapan-ungkapan beliau bahwa keunggulan nasib banyak ditentukan oleh kegigihan seseorang, bukan semata-mata mutlak ditentukan Tuhan. Makna teologis yang lebih nyata masih dianggap tidak ditonjolkan berdasarkan pemahaman mendalam. Walaupun demikian, keyakinan dan kepercayaan kepada Tuhan yang kuat membantu kesuksesan, tidak serta merta lahir, kalau tidak diperjuangkan oleh potensi diri yang dominan dalam setiap langkah berusaha, terutama dalam berbisnis. Sentralisasi keberuntungan hidup dan nasib masih kuat dipegang sebagai upaya mandiri. Tuhan hanya mengasih rizki yang diperjuangkan dengan kerja keras, tidak serta merta didapatkan hanya dengan menunggu rizki datang dari langit.

\section{Kesimpulan}

Dengan demikian nilai-nilai teologis dalam perilaku dan etika bisnis Orang Sunda dapat diindikasikan sebagai berikut: Pertama, aspek-aspek etika yang muncul dalam perilaku bisnis mereka, seperti kejujuran, kepercayaan dan keadilan termasuk yang dipegang teguh. Kejujuran diprioritaskan dalam merintis karier menuju puncak sukses, menurut H. Agus, yang meniti usaha dari kecil-kecilan, semenjak pertama kali sejak tahun 1991 di bidang pertambangan, kejujuran sebagai kunci dia dipercaya mendapatkan modal dari bank. Begitu juga kepercayaan dan janji-janji berusaha sesama kolega dan bawahan mutlak diprioritaskan. Hanya kadangkala justru mitra lain terutama perusahaan besar di Jakarta, bisa 
saja mengabaikan aspek kepercayaan yang sudah disepakati.

Sementara ini, mereka berpengalaman "kanyang" (sudah penuh pengalaman) dalam hal dibodohi dan didustai oleh kolega di jakarta, secara sepihak yang mengabaikan pembayaran atau menunda proses pencairan pembayaran hutang mereka. Ketika hal demikian terjadi mereka tidak bisa berbuat banyak.

Begitu juga makna keadilan, sementara ini mereka berusaha membagi keuntungan secara real bahkan di atas gaji rata-rata perusahaan besar (UMR), minimal gaji di lapangan seorang mandor (pengawas 1 juta perbulan). Jika dibanding perusahaan kapas (alat kecantikan) yang hanya mengaji mandornya 900 ribu perbulan. Termasuk tambahan uang transportasi, pemeliharaan kendaraan roda dua jenis honda untuk oprasional di lapangan. Sementara pelacakan di lapangan, tidak ada karyawan dan mandor yang mengeluhkan gaji atau insentif yang diberikan perusahaan.

Kedua, Aspek teologis yang muncul ke permukaan tentang realitas di lapangan, menunjukkan bahwa H. Agus termasuk pengusaha yang menggabungkan nilai-nilai agama dalam berbisnis, seperti khusus menyediakan dana untuk kepentingan sosial dan pembangunan tempat ibadah (lembaga pendidikan seperti pesantren). Anggaran yang disediakan lumayan besar ratusan ribu rupiah, bahkan sampai puluhan juta rupiah perbulan. Termasuk yang menarik, khusus untuk kaum dhuafa dan pengajar yang mengabdi di pesantren atau sekolah yang ada di Cikancung, diberi santunan oleh perusahaan BGP.

Berdasarkan dua fenomena di atas praktek bisnis orang Bandung telah menunjukkan gejala penerapan teologi modern. Hal ini diindikasikan dari kinerja perusahaan Batu Gunung Padakasih (BGP) yang terletak di Cikancung Kabupaten
Bandung yang di pimpin $\mathrm{H}$. Agus, termasuk kategori modern dan tradisional, dalam hal manajemen. Walaupun demikian, secara aplikasi tampaknya perlu menambahkan proses pengambilan keputusan bisnis, masih diperlukan melibatkan tokoh-tokoh bisnis, atau jajaran puncak lainnya. Kendati H. Agus termasuk direktur utama perusahaan, namun ia masih perlu melibatkan yang lain dalam pengambilan keputusan. Sementara ini keputusan berada di tangan satu orang, yaitu terletak di tangan direktur utama.

Praktek bisnis orang Bandung yang ada di dalam perusahaan BGP (Batu Gunung Padakasih) yang sudah termasuk modern, dengan menonjolkan profesionalisme, mempunyai visi dan misi bisnis, mengaplikasikan manajemen bermutu dan maju, pengelolaan modal yang besar dengan bermitra kepada pemodal lain seperti bank, dan pembagian keuntungan berdasarkan standar nasional bahkan di atas UMR, dengan legalitas usaha jelas seperti punyai akta notaris, NPWP, ID, HO (izin lingkungan) dan kuasa pertambangan (KP) dengan aset triliunan rupiah. Walaupun demikian, secara aset manajemen tradisional dalam pengelolaannya juga masih nampak, misalnya pengeluaran keuangan masih ada melalui direktur utama, dan pendelegasian wewenang langsung dari pimpinan puncak.

\section{Daftar Pustaka}

\section{Buku Teks}

Alfani, Daud, Islam dan Masyarakat Banjar (Jakarta: PT. Raja Grafindo, 1997).

al-Syahrastani, Al-Milal Wa an-Nihal, I (Kairo: Dar al-Fikr, 1951).

Anshary, Hafiz AZ. "Keberagamaan Orang banjar", dalam Laporan Penelitian Abdul Sani, Islam dan Etika Bisnis Pengusaha Banjar di Kalimantan Selatan, (Banjarmasin: Pusat Penelitian IAIN Banjarmasin, 2001). 
Degobart, D Renes, Dictionary of Philosophy, (Now Jersey, Leftlefield, Adam and Co, New Jersey, 1976).

Des Jarden and Mac Call, Contemporery Issues in Businees Ethics (California: Word worth Publishing Company, 1989).

James, William, Religious Experience (New York: Hand books, American University, 1986).

Norman, R. Soderberg, Public Relation for The Entrepreneur and Growing Business, (Chicago: Illionis Probus Publishing Company, 1986).

Paul E. Johnson, Psychology of Religion (New York: Abingdon Press, 1959).

Paul, Edward, The Encylopedia of Philosophy (London \& New York: Macmillan Publishing \& Co, 1972).

Vincent, Barry, Applying Ethics (California: Worth Publishing Company and Wads Worth, 1989).

\section{Jurnal}

Asyari, Asyari, "Model Strategi Bertahan Hidup Rumah Tangga Miskin (Sebuah Literature Review)", Islam Realitas: Journal of Islamic \& Social Studies, 2.2, 2016.

Collins, D. "Designing ethical organizations for spiritual growth and superior performance: An organization systems approach", Journal of Management, Spirituality and Religion, Vol. 7, No. 2, 2010.

Donaldson, John and Irene Fafaliou, "Business Ethics, Corporate Social Responsibility and Corporate Governance: a Review and Summary Critique", European Research Studies, Vol. VI, No. 1-2, 2003.

Irham, Mohammad, "Etos Kerja dalam Perspektif Islam", Jurnal Substantia, Vol. 14, No. 1, 2012.

Izmuddin, Iiz, "Menata Regulasi Pegadaian Syariah (Upaya Menerapkan AlMaqasid dan Meminimalkan Kesenjangan Sosial)", Islam Realitas:
Journal of Islamic \& Social Studies, 2.2, 2016.

Jahja, H. M. Zurkani, "Etos kerja dan Teologi Asy’ariyah”, Jurnal Antasari, X, 1988.

Kaelber, Lutz, "Max Weber's Protestant Ethic in 21st Century", International Journal of Politics, Culture and Society, Vol. 16, No. 1, 2002.

Miharja, Deni, "Keberagaman Masyarakat Adat Cikondang dalam Menghadapi Modernisasi", Islam Realitas: Journal of Islamic \& Social Studies, 1.1, 2015.

Musa, A.O. "Perceived role of ethics and social responsibility in the insurance industry: Views from developing country", Journal of Knowledge Globalization, Vol. 1, No. 2, 2008.

Rahman, Addi, "Pos-Islamisme "Ilmu" Ekonomi Islam di Era Urban dan Multikulturalisme", Islam Realitas: Journal of Islamic \& Social Studies, 1.2, 2015.

Ramadhan, Bagus Mohammad dan Muhammad Nafik Hadi Ryandono, "Etos Kerja Islami pada Kinerja Bisnis Pedagang Muslim Pasar Besar Kota Madiun", JESTT, Vol. 2, No. 4, 2015.

Thaib, Erwin Jusuf, "Al-Qura'an dan AsSunnah Sebagai Sumber Inspirasi Etos Kerja Islami”, Jurnal Dakwah Tabligh, Vol. 15, No. 1, 2014. 